\title{
XXXVII. History of astronomy for the year 1801
}

\section{Jerome Lalande}

To cite this article: Jerome Lalande (1802) XXXVII. History of astronomy for the year 1801, Philosophical Magazine Series 1, 12:47, 203-211, DOI: $10.1080 / 14786440208676052$

To link to this article: http://dx.doi.org/10.1080/14786440208676052

$$
\text { 曲 Published online: } 18 \text { May } 2009 .
$$

Submit your article to this journal

LII Article views: 2

Q View related articles $\asymp$ 
the vitrid mals was minutely examined, but no metallic globule was vifible. The mixture before fution was magnetic, owing to the oxide. This property was now entirely loft.

The heat of this experiment was urged moderately, that time might be given for the exertion of any affinity, if fuch exifted, betwixt the iron and the carbonic acid, or betwixt the oxide of iron and the carbonaceous part of the acid. No portion of metal being revived, $I$ conceived this a moft conclufive proof of the nondecompolition of the carbonic acid.

XXXVII, Hiftory of Afronomy for the Year 1801. By JEROME LALANDE.

[Concluded from p. 12\%.]

II. BODE, of Berlin, has publifhed the laft part of his large Celeftial Atlas in twenty theets, which contains all the old conftellations, with feveral new ones, and fome thoufands of ftars, with which I furnilhed him; an immenfe labour, of which the aftronomers had need. This beautiful work may be procured at the Collége de France.

On the $27^{\text {th }}$ of September the Helvetic republic adopted the French meafures. This is the firft of the European ftates which has been fenfible of the importance of this univerfal meafure to the general good of civilized nations.

Guglielmini, of Bologna, has made three new experiments on the fall of bodies, to prave the rotation of the earth : be has found the fame deviation from the fouth within a line, though it is not given by theory; but the deviation from the weft he has found as it ought to be. Preparations are making for obfervations of the fame kind at Hamburgh from the tower of St. Michael, at the height of 326 feet.

The obfervatory of Cadiz, during feveral years, has furnifhed us with a feries of important obfervations; but for fome time it has been neglected. General Mazzaredo has caufed a new one to be built in the Ilde-de-Leon, and he has attached to it four aftronomers, officers in the navy-Rodrigo Armefto, Maximo-Lariva Aguero, Julian Canela, and Jofeph Cuefta, who have refided there four years. For ten years paft, a nautical almanac has been publifhed in Spain. I hope navigation and aftronomy will be benefited by it. The telefcope 25 feet in length, made by Dr. Herfchel for Spain, will be fent off in the month of January; and Dupont will go to Spain to mount it.

M. Travalfos, 
M. Travaffos, fecretary of the Academy of Lifbon, has fent me obfervations by $M$. Ciera, which have confirmed the longitude of that city; the Nautical Ephemerides publithed to 1803, and various works of the Portuguefe Academy, of which we had no idea, and which the National Inftitute of France received with much intereft. This negotiation was conducted by the chevalier d'Aranjo.

Aftronomy was long in a languifhing condition in the Batavian republic: $M$. Fokker has eftablifhed, at his own expenfes, an obfervatory at Middleburg; he has purchafed inftruments, and fent us feveral obfervations made between 1797 and $1801 . M$. Fokker, during the revolution of 1795 , was member of the committee of public fafety, and at that time obtained a tower in the abbey; but the revolution of the 12th of June 1796 interrupted his plans for the improvement of the obfervatory. He is now engaged in the finance department of Zealand; but his fpare time is employed on aftronomy, and he has fent me feveral interefting obfervations.

In Germany aftronomy continues to be cultivated with great affiduity. Baron Von Zach's tour to Bremen and Lilienthal has produced new activity; and the fociety formed for the purpofe of fearching the heavens are ftill occupied with that object. He obferves the moon with great diligence; and gives me reafon to hope, that I thall fee next fummer $a$ part of the German aftronomers affemble in an aftronomical congrefs at Gotha, as was the cafe in 1798. Amidft the horrors of war, the French aftronomers fignalized their zeal for aftronomy. General Moreau,' being at Cremsmunfter, where there is a celebrated obfervatory, caufed a bill to be potted up denouncing the punifhment of death againft every perfon who thould be guilty there of any depredation; and neither the obfervatory nor the convent of the Benedictines fuftained any injury. It is flattering to the French to have officers who diftinguifh themfelves by a tafte for the fciences. It will no longer be faid that military men, in confequence of their fituation, are ignorant and ferocious.

The Academy of Peteriburgh has requefted an obferver, but Burg and Wurm have been retained by their fovereigns; and this beautiful obfervatory is fill ufelers, notwithftanding the number of excellent inftruments with which it is furnifhed.

C. Henry has had the fatisfaction of erecting the large mural quadrant by Bird, and of making fome obfervations with it.

The irregularity in the degrees of the earth hitherto meafured, 
fured, gave reafon to fufpect fome error in that of Lapland meafured in 1736. M. Melanderhielm, therefore, has obtained permiffion from the king of Sweden to undertake a new meafurement. In the month of April Meffrs. Ofverbom and Swamberg fet out for Tornea, where they erected fignals and built fmall obfervatories. When the ice on the river is thawed, they will meafure a bafe with the rules fent them by the Inftitute. A multiplying circle, made at Paris by Lenoir, will ferve them in the fpring for meafuring the angles; and next fummer we mall have the folution of this old difficulty.

M. de Mendoza, a Spanifh officer, has publithed two large collections of tables; one at Madrid, in 1800, entitled Colleccion de Tablas; and another at London, in the month of April I80I, which contains tables for the reduction of diftances by the addition of five natural numbers : he has made a new ufe of the verfed fines, which renders numerical operations fhorter and eafier. Thefe tables confift of 407 pages quarto.

M. Garrard has publifted tables in thirteen pages only; but his method is neither fhorter nor fo accurate.

Mr. Vince, an able Englifh aftronomer, has publifhed the fecond volume of a large treatife on aftronomy.

The ftereotype tables of logarithms, publithed by Firmin Didot in 1795, have been again corrected. M. Vega, who has caufed to be printed in Germany the largeft collection extant, has verified the French tables, and fent us feveral faults, which are going to be correeted: in all probability they will be the laft, and we may depend in future on correct tables. This is a great benefit for calculators, who have fometimes loft whole days in revifing calculations, which did not agree, in confequence of an erroneous figure.

But as the fmall manual tables are moft frequently employed, I have caufed them to be printed in ftereotype: feveral perfons have corrected them; and in three months I can give all calculators the moft correct, moft convenient, and moft elegant edition that has ever appeared.

C. Verniquet has finifhed the engraving of his large plan of Paris in 72 theets on a fcale of half a line to the toife, which in correctnefs furpafies every thing of the kind.

A project was long ago formed and undertaken for making a lunar globe reprefenting all the mountains and craters. Mr. Ruffel has accomplifhed this object in England: his lunar globe, mounted on an ingenious ftand, expreffes all the circumftances of the moon's libration, and fhows that body as the ought to appear in the different pofitions of the 
earth and moon, as well as the variations of the equator and orbit.

M. Philippides, born at Mount Pelion in Theffaly, who attended the courfe of aftronomy at the Collége de France in 1794, and who is now at Jaffi with the hofpodar of Moldavia, propofes to publifh in Greek the Abridgement of my Aftronomy: he has already publithed various works, for the purpole of endeavouring to propagate inftruction in his country.

Three-fourths of the two laft volumes of Montucla's Hiftory of the Mathematics are printed. This work will contain the hiltory of altronomy, optics, and navigation; to which I have been obliged to make great additions in confequence of the too premature death of the learned author.

M. Von Murr, of Nuremberg, who has manufcripts of Regiomontanus, the firft reftorer of aftronomy before 1500 , has caufed a page to be engraven, an exact fac-fimile of the character of the manufeript: he offers to fell thefe manufcripts for 2400 francs; they would be a treafure to a large library.

The aftronomical poems of Ricard, Lemiere, and Fontanes, had before thown how far a view of the heavens is capable of exciting poetical enthufiafm. C. Gudin has again proved it by a poem, which contains both the hiftory of aftronomy and a defcription of the heavens, and which difplays as much correctnefs as elegance.

This year geography alfo has made confiderable progrefs. Tranchot is contructing a map of the four united departnuents on the fcale of a line to roo toifes: a furvey is taking of the country between the Adige and the Adda, Piedmont, Swabia, and Swifferland; and the minifter at war caufed the details to be inferted in the Moniteur of Auguit I 4 .

C. Henry, who has been invited to Munich to conftruct the map of Bavaria, informs me in a letter that the topographical part is in great forwardnefs; a bafe of 21,649 metres or I I, 108 toifes has been meafured: it is the longeft ever meafured. The large triangles around the capital are already in part clofed. There are fome the fides of which will be from 15 to 20 leagues, and even more. He has already fwept the horizon feveral times with his circle, and with aftonifhing precifion. The laft fweep was compofed of fix angles; the fum of which when reduced was not in excefs, but 8-1oths of a fecond in 360 degrees; and yet the circle he ufed was not very good. To make up as much as poffible for what may be wanting in regard to precifion, he multiplies his obfervations: he never makes leis than I $_{5}$ conjugate obfervations, 
tions, and he often carries the number to 20. The triangles which Caffini affumed in the neighbourhood of Munich are badly chofen, and the meafurement of them is very incorrect. Without employing his triangles, Henry has already difpofed a feries of 14 triangles, the meafure of which will give us that of an arc of the meridian of fomewhat more than a degree : he hopes that it will ftill be poffible to prolong this arc, which will pafs at a little diftance from Ingoldftadt, and which will afcertain the pofitions of a part of Germany. The travels of baron. Von Zach and feveral of his co-operators have alfo fupplied us with new information and new pofitions, which will improve the geography of Germany. $\mathrm{Co}$ lonel le Cocq continues his map of Weftphalia.

Baron Von Ende, member of the fupreme conncil of appeal at Cette, has publifhed a volume on the determination of feveral places in Lower Saxony: it is filled with obfervations and calculations.

The geography of diftant countries bas affumed alfo a new activity. Captain Baudin, whofe royage of difcovery 1 before announced, left the Canaries on the zath of November, and the Ifle of France on the $22 \mathrm{~d}$ of March. We have reafon to hope that he has already made interefting difcoveries in New Holland; the only country of the earth which is almont unknown to us, though it is 2000 leagues in circamference. Bernier, the aftronomer who accompanies him on the expedition, a man of intelligence and courage, leaves nothing to be withed for on that hesd. In the month of June the French government granted paffports to the Exiglifh reffels, the Inveftigator, captain Flinders, on the point of proceeding on a voyage of difcovery to the South Seas, and to the Lady Nelfon, commanded by lieutenant Grant, who is to accompany the Inveftigator, in exploring the coafts of Now Wales.

C. Deguignes jun., arrived from China, where he refided from 1784 to 1797 , will, in all probability, when he publithes the journal of his voyage, give us fome information refpecting that beautiful part of the world.

Baron Humboldt, an enlightened and intrepid philofopher, has gone to South America, where he has travelled 1300 leagues in the deferts, with great lebiour and amidet terrible dangers, to make us acquainted with the geography and natural hiftory of thofe countries which are ftill new to us.

M. Deferrer has fent me obfervations which give the pofition of Natchetz in Louifiana, and of Guaira in South America; for the former, lat. $31^{\circ} 33^{\prime} 4^{\prime \prime}$, difference of meridian $6^{\mathrm{h}} 15^{\prime} 21^{\prime \prime}$; and for the latter $10^{\circ} 36^{\prime} 40^{\prime \prime} \mathrm{N}$. and $4^{\mathrm{h}} 37^{\prime} 11^{\prime h}$. 
C. Nout has fent us from Egypt an almanac calculated for that country, and feveral pofitions of cities even in Upper Egypt, notwithitanding the climate, the dangers, and inconceivable labour which fuch obfervations require. The value of the degree is 56,880 toifes; the Egyptian ftadium 711 feet; the Egyptian cubit $2 x^{\prime} 33$ inches; the Greek fadium 487.543 feet, and the cubit 19.5017 inches. In a word, he has arrived himfelf, and brought us the continuation of his labours, accompanied with young Ifaac Mechain, the fon of one of our moft celebrated aftronomers, who was his companion and co-operator in Egypt. C. Fourrier has brought us drawings of the zodiacs of Upper Egypt, which atteft the high antiquity of aftronomy; and he proves that the formation of the conftellations goes back 14,000.years, as. Dupuis prefumed.

C. Marquis, præfect of La Meurthe, has fent to the Board of Longitude obfervations and manuferipts of P. Barlet; a jefuit of Nancy, which contain interefting things.

I mult here fay a word of meteorology $\therefore$ C. Lamarc has 'publifhed a meteorological journal, in which' he gives a great many obfervations, and indicates the variations of the:feafons which may be fuppofed to take place in the courfe of the year. The minifter of the interior has eftablifhed a meteorological correfpondence to multiply obfervations; and Lamare, who folicited this eftablithment, will make it advantageous to the feience, which is ftill in its infancy.

C. Burekhardt, alfo, has written a Jong and curious work on meteorology: He has examined 15,000 obfervations of the barometer, that he may be able to calculate the influence of the 'winds; and he has found that the fouth wind gives for mean height 27 inches $11 \cdot 3$ lines, while the eaft gives 28 inches $1: 9$ line. He has found alfo that the height on the borders of the Mediterranean fea is 28 inches $2 \cdot 2$ lines, and on thofe of the ocean 28 inches 2.8 lines.

Well placed weather-cocks are very rare at Paris. There is none at the obfervatory, though I requefted one on being appointed director; and $I$ have thanked, in name of all obfervers, C. Bois, tinman, who having built a houfe on the Quai des Auguftins, has erected there.a lofty and very moveable weather-cock, widh letters indicating the four cardinal points, which will be on a line with a meridian I have traced out on the quay. Aftronomers, when they go to the Inftitute or the Board of Longitude, will have an opportunity of feeing conveniently the direction of the wind; and the fame advantage will be enjoyed by the inhabitants of that vaft quay, of the Louvre, and the furrounding houfes, which 
had not a fingle weather-cock in their view, but a great many conductors, which are not very interefting.

On the $3 \mathrm{~d}$ of November there was in the Baltic a terrible ftorm, which deftroyed fome veffels, and was felt even at Breft. On the $7_{\text {th }}$ there was a form in Provence, which produced 73 lines of water in $2 \frac{1}{2}$ hours by a wind at S.S.E. It did very great damage at Marfeilles; feveral perfons perifhed in the neighbourhood, and the lofs amounts to fome millions. C. Thulis has found fome memorandums of the ftorms of July 12, $174^{8}$; September $4,1_{7} 6_{4}$; and Septeinber 15, 1772: but no perfon had any remembrance of a ftorm like that of the prefent year. The plain of the Po was expofed to an immenfe inundation.

The Clafs of the Phyfical and Mathematical Sciences on the I6th of April chofe three altronomers, who were prefented to the general affembly for the place of affociate, vacant by the death of C. St. Jicques, viz. C. Vidal, Sepmanville, and Bernard.

The firft is an uncommon obferver, who has alone made more obfervations of Mercury than all the altronomers of the world fince 2000 years. The fection of aftronomy had prefented alfo C. Pictet of Geneva, Chabrol (de Riom), and Quenot, officers in the navy. I even made out a lift of the aftronomers known in France, which contained C. Henrv, returned from Peterfburgh; Nouet and Beauchamp, returned from the Levant; C. Deratte and Poitevin, of Montpellier; Bernier and Biffy, who embarked with captain Baudin; Chevalier, in the department of foreign affairs ; Kramp, of Cologne; Duvaucel, at Evreux; Guerin, at Amboife; Mongin, at la Grand-Combe-des-Bois ; Maingon and Lancelin, at Breft; Jacotot, at Dijon; Planpain and Degrand, at Marfeilles. If we add to thefe the fix aftronomers affociated at the Inftitute, it will be feen that this f'cience, the molt tunprofitable and the mott neglected, ftill furnithes fubjects in France. As foon as the happy event of peace exalted the hopes of literary men, I took advantage of it to folicit from all quarters, that aftronomy might participate in the benefits of it.

The Academy of Peterfburgh has tranfmitted to me a fmall prefent, which it has been accuftomed for thirty years to fend me for the good of altronomy; and the emperor of Ruffia has approved the defire of the Academy in that refpect.

The king of Etruria has promifed to patronize aftronomy at Florence. The obfervatory is already provided with excellent infruments, and Fabroni has affured me that an obferver will be placed in it: he has requefted one of my puVoz. XII, No, 47. 
pils; and this circumftance makes me regret that I have not a greater number.

General Jourdan gives me reafon to hope that the obfervatory of Turin will be put in a proper ftate; and C. Vaffalli, prefident of the academy, affords me hopes alfo.

The minifter of the marine has given orders that new obfervations thall be made at Breft on the tides, according to my requeft, in order to complete my Traite du Flux et du Refuxix de la Mer, which I wrote to confirm the excellent theory of Laplace in his Mécbanique Célefte, and to afcertain what influence the wind has on the tides.

We requefted the firft conful to procure us from Spain two thoufand pounds weight of platina, to conftruct a telefcope of $3^{6}$ feet; and we have reafon to hope for it. Our telefcope will, perhaps, furpals that of Herfehel.

The obfervatory of Paris has acquired C. Agouftene. The minifter of the interior, C. Chaptal, has agreed that the Board of Longitude may increafe its expenfes for this new affiftant; and I. have obtained C. Giroult, whofe youth and affiduity give me new aid, and leave me no other regret than that of not being able to procure a greater number.

In my Hiftory of Aftronomy for 1800 , I mentioned the lofs which aftronomy had fuftained on the 5 th of November that year by the death of Ramfden: to him we have been indebted, during the courfe of twenty years, for the beft and largeft infruments, the moft perfect telefcopes, and the mult ingenious ideas. Troughton, at prefent is the matt celtbrated artift in England, and is prepaping to indémnify us for this lofs. He has already made excellent inftruments; and C. Pictet, of Geneva, lately brought us fome of them.

On the Ioth of February we loft C.iSt. Jacques de Sylvabelle, director of the obfervatory of Marfeilles, who diftinguifhed himfelf by theoretical refearches in .17.53, as may be feen in the Philofophical Tranfactions, and then by 4 feful obfervations: he was 79 years of age, and was ftill ufefully employed, His eulogy will appear in the journal of the Lycæum of his department.

He has been fucceeded by Thulis, who has long been affiftant director of the obfervatory. The katter made profelytes and pupils C. Planpain and C. Degrand; but they have both left us, to the great lofs of aftronomy.

In the month of December I800, Matteucci died at Bologna : to him we are indebted for the laft volumes of the Ephemerides of Bologna, which go as far as 1810. He has been fucceeded by C. Ciccolini and Guglielmini, who promife new activity in the obfervatory, which Manfredi, Za- 
notti, and Matteucci, have rendered interefting for a century paft.

Chaligni died lately at Madrid; he had long made obfervations and calculations, by which he has been known with advantage as an aftronomer.

M. Chevalier has died at Prague : he made ufeful obfervations at Lifbon in 1759 , and at Bruffels.

On the 8th of October, Gabriel de Bory died at Paris, aged $8 \mathrm{I}$ : he undertook a journey to Spain in $175 \mathrm{I}$, and in I 758 went to Portugal and Madeira to determine their pofition. His obfervations are in the Medmotres of 1768 , p. 270 , and in thofe of 1772 , part ii. In the Mémoires of 1770 he gave a defcription of a portable obfervatory, and in the third volume of the Savins Etrangers an obfervation of the tranfit of Mercury in 1753. In $175^{1}$ he publifhed a defcription of a marine octant: he diffufed a tafte for obfervations through the royal navy: being chef d'efcadre and governor of the windward inlands, he had means of contributing to excite emulation, and he always employed them. In 1765 he was therefore elected a frea affociate of the Academy of Sciences, and in 1798 niember of the Inftitute.

The Academy and Inftitute have always been fenfible how much need we have of enlightened fellow-labourers to improve our knowledge of navigation, the moft difficult of all arts, and the moft important of all fciences for the profperity and greatnefs of tates.

But the greateft lofs futtained by aftronomy is that of Jofeph Beauchamp. He was born at Vezoul on the 29th of June 1752 . His obfervations at Bagdad in Perfia, and on the Black fea, were as laborious to him as they were important to us. He fet out in 1795 as French conful for Mafcate in Arabia; and he wrote to me on his departure as follows: "Remember my attachment to you and to aftronomy." He left indeed, with fome regret, a country and family who were dear to him: he is certairily one of the martyrs to aftronomy. He fet out for Conftantinople on the $25^{\text {th }}$ of September; we expected him with the greateft impatience, but he had fcarcely arrived in Provence when he fell a prey to a malady of which he had not been properly cured. He died at Nice on the Igth of November 1801. Eight days before his death the fection of aftronomy had prefented him to the vacant place in the Inftitute: I publifhed a notice of his labours in the Moniteur of Dec. $15 ; 1801$. 